\title{
Malted Sorghum-Soy Composite Flour: Preparation, Chemical and Physico-Chemical Properties
}

\author{
Bolarinwa IF $^{1 *}$, Olaniyan SA ${ }^{1}$, Adebayo LO ${ }^{2}$ and Ademola AA ${ }^{1}$
}

${ }^{1}$ Department of Food Science and Engineering, Ladoke Akintola University of Technology, P.M.B. 4000, Ogbomoso, Oyo State, Nigeria

${ }^{2}$ Department of Chemical Sciences, Crescent University, Abeokuta, Ogun State, Nigeria

\begin{abstract}
In the present study, the effect of soy flour fortification on the chemical and physico-chemical properties of malted sorghum flour for probable industrial uses was investigated. Malted sorghum-soy composite flour was prepared by mixing malted-sorghum flour with soy flour at varying proportions $(0-40 \%)$. The composite flour mixes were evaluated for proximate and mineral composition, anti-nutritional factors and functional properties. Reconstituted thick paste "amala" prepared from all the samples were evaluated for consumer acceptability. The results showed increment in the proximate content of the composite flour as the ratio of the soy flour in the mixes increases. The protein content of the flour mixes increased from $7.3 \%$ to $19.2 \%$. The blend containing $40 \%$ soy flour substitution had the highest protein, fat, ash and fiber content. The mineral content increased while the anti-nutritional factors decreased as the soy flour substitution increases in the mixes. The functional properties of the flour decreased while the pasting viscosity and $\mathrm{pH}$ increased. Reconstituted thick paste produced from $10 \%$ soy flour substitution was most acceptable in terms of the sensory properties. The results obtained in this study indicated that highly nutritious flour can be produced from malted sorghum-soy composite flour.
\end{abstract}

Keywords: Malted-sorghum flour; Soy flour; Composite flour; Proximate composition

\section{Introduction}

Composite flour is a mixture of different flours from cereal, legume or root crops that is created to satisfy specific functional characteristics and nutrient composition. It could be a mixture of wheat flour (usually more than $80 \%$ ) with other flours such as maize, rice, sorghum etc (usually less than 20\%). The use of composite flour based on wheat and other cereals including minor millets in bakery products is becoming popular because of the economic and nutritional advantages of composite flour. Nigeria has unfavorable climatic condition for wheat cultivation but suitable for tropical crops such as legumes, roots, tubers and cereals. Therefore, consumption of cereal based foods like biscuits, bread and other baked products require development of an adequate substitute for wheat [1].

Sorghum (Sorghum bicolor [L] Moench) is one of the most underutilized crops in the semi-arid tropics of Asia and Africa. It is the principal source of energy, protein, vitamins and minerals for millions of the poorest in these regions [2]. Sorghum products are deficient in essential amino acids such as lysine, methionine, tryptophan and the presence of anti-nutritional factors such as tannins and phytates limit their nutritional value. The nutritional quality of sorghum and millets especially the former is poor. Therefore, attempts have been made to fortify these cereals with legumes or other cereals to make it nutritionally superior and acceptable product. Sorghum has been successfully used in feeding programs after fortification with legumes. Various infant mixes based on sorghum and pearl millet, fortified with soybean flour has been developed [3].

Soybean (Glycine max) is a cheap source of quality protein that is superior to all other plant foods because it has good balance of the essential amino acids and it contains a reasonable amount of methionine lacking in sorghum, making it a good supplement for cereals. Soybean is one of the richest and cheapest sources of plant protein that can be used to improve the diet of millions of people, especially the poor and low income earners in developing countries because it produces the greatest amount of protein used as food by man [4]. Nutritionally, soybean protein resembles animal protein more closely than other vegetable proteins. Soybean protein constitutes about $40 \%$ of the total solids and plays a very important role in the enrichment of cereal-based baked goods. It is also a rich source of vitamin, minerals and is relatively low in crude fiber [5]. Soybean is a good source of protein, which when used partially to replace or complement wheat flour in the production of bakery products such as biscuits, bread and other confectionery could go a long way in improving the nutritional status of the final product [6]. Hence this work was aimed at determining the effect of soy flour additions on the chemical and physicochemical properties of malted-sorghum flour for probable industrial use.

\section{Materials and Methods}

\section{Plant materials and reagents}

Sorghum grains and soybeans used for this study were purchased from a local market in the Southwestern part of Nigeria. All the reagents used in the study were of analytical grade. The experiment was carried out at Food Science and Engineering laboratory, Ladoke Akintola University of Technology, Ogbomoso, Nigeria.

\section{Preparation of malted-sorghum flour}

The method of Hallen et al. [7] was used to prepare malted-sorghum

*Corresonding author: Islamiyat Folashade Bolarinwa, Department of Food Science and Engineering, Ladoke Akintola University of Technology, P.M.B. 4000, Ogbomoso, Oyo State, Nigeria, Tel: (234) 8022526700; E-mail: islamiyat202@yahoo.co.uk

Received July 09, 2015; Accepted July 24, 2015; Published July 31, 2015

Citation: Bolarinwa IF, Olaniyan SA, Adebayo LO, Ademola AA (2015) Malted Sorghum-Soy Composite Flour: Preparation, Chemical and Physico-Chemical Properties. J Food Process Technol 6: 467. doi:10.4172/2157-7110.1000467

Copyright: (c) 2015 Bolarinwa IF, et al. This is an open-access article distributed under the terms of the Creative Commons Attribution License, which permits unrestricted use, distribution, and reproduction in any medium, provided the original author and source are credited. 
flour. The sorghum grains $(2 \mathrm{~kg})$ were sorted to remove stones, dirt and other extraneous materials. The cleaned grains were thoroughly washed and steep in water for $12 \mathrm{hrs}$ so as to attain a $42-46 \%$ moisture level. The hydrated grains were spread on a moist jute bag which had been previously sterilized by boiling for 30 minutes and the grains were allowed to germinate for four days. Non-germinated grains were discarded and the germinated seeds were dried at $60^{\circ} \mathrm{C}$ in a cabinet dryer to a moisture content of $10-12 \%$. The withered rootless grains were gently brushed off, and the malted grains were dry milled, sieved and packaged in an air tight container until ready for used. The flow chart for the production of malted-sorghum flour is shown in Figure 1.

\section{Preparation of soy flour}

Soy flour was prepared according to the method described by Ndife et al. [8]. The soybeans $(1 \mathrm{~kg})$ were thoroughly cleaned to remove dirt and other extraneous materials such as stones and sticks. It was then washed and oven dried. The soybeans were roasted, decorticated, winnowed and milled into fine flour using hammer mill (model EU $5000 \mathrm{D}$ ) and sieved through $250 \mu \mathrm{m}$ aperture sieve (Figure 2). The flour was packed and sealed in polyethylene bags until analyzed.

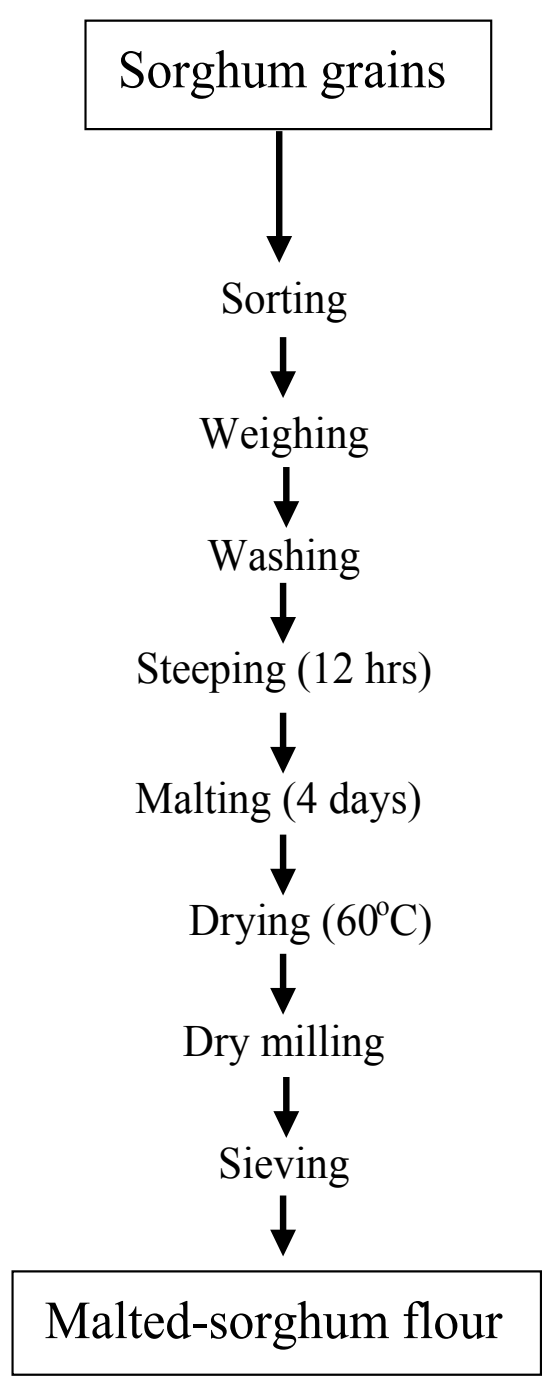

Figure 1: Flow chart for the production of malted-sorghum flour.

\section{Composite flour preparation}

Malted sorghum-soy composite flour were prepared by blending malted-sorghum flour with soy flour at varying proportions; 100:0, $90: 10,80: 20,70: 30$ and 60:40 respectively. The flour blends were individually packaged in a sealed polyethylene bags and kept at room temperature until used for analysis. Wheat flour (100\%) was used as control (Table 1).
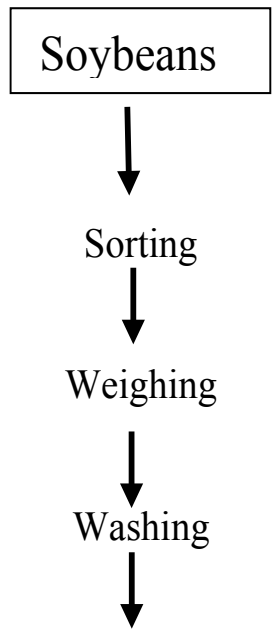

Oven drying $\left(60^{\circ} \mathrm{C}\right.$ for 6 hours $)$<smiles>C1CCCCC1</smiles>

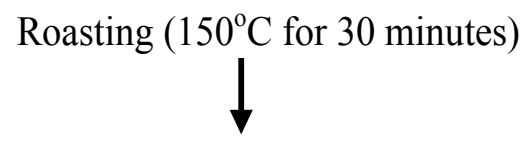

Decortication/winnowing

Fine milling

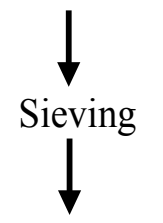

Soy flour

Figure 2: Flow chart for the production of malted-sorghum flour.

\begin{tabular}{|c|c|c|c|}
\hline Samples & $\begin{array}{c}\text { Malted-sorghum } \\
\text { flour (\%) }\end{array}$ & Soy flour (\%) & $\begin{array}{c}\text { Wheat flour } \\
\text { (\%) }\end{array}$ \\
\hline A & 100 & 0 & 0 \\
\hline B & 90 & 10 & 0 \\
\hline C & 80 & 20 & 0 \\
\hline D & 70 & 30 & 0 \\
\hline E & 60 & 40 & 0 \\
\hline F & 0 & 0 & 100 \\
\hline
\end{tabular}

Table 1: Composition of the malted sorghum-soy flour mixer. 


\section{Chemical analysis}

The composite flour mixes were analyzed for moisture content, crude protein, crude fat, ash and crude fiber content according to the method described by AOAC [9]. The carbohydrate content of the flour mixes were determined by difference. Minerals including iron, calcium, zinc and phosphorous were extracted from dry ash samples and determined using atomic absorption spectrophotometer.

\section{Physical and physico-chemical properties}

The bulk densities of the composite flour mixes were determined by the method of Okaka et al. [10]. The swelling capacity was determined by the method described by Sanni et al. [11]. The method described by Lawal and Adebowale [12] was employed in determining the water absorption capacity of the flour mixes. The $\mathrm{pH}$ of all the samples was determined using the method described by AOAC [9]. Pasting characteristics were determined using Rapid Visco Analyzer (Newport Scientific, RVA super IV).

\section{Determination of anti-nutritional factors}

The method of Swain and Hillis [13] was used for the determination of tannin contents of the composite flour. Phytate was determined using the method described by AOAC [9].

\section{Sensory evaluation}

The five samples obtained from the different fractions of sorghumsoy mixes were made into thick paste (a popular west African food known in Nigeria as "amala")using about $200 \mathrm{~g}$ of flour and $50 \mathrm{ml}$ of boiling water. The samples were rated on the following quality attributes; aroma, texture, color, taste and overall acceptability using 9 point hedonic scale. The scores obtained were subjected to analysis of variance at $5 \%$ level of significance and means were separated using Duncan Multiple Range Test.

\section{Statistical analysis}

All data obtained were subjected to analysis of variance (ANOVA), and significant means were separated using the Duncan Multiple range (DMR) test with significance level at $\mathrm{p}<0.05$ [14].

\section{Results and Discussion}

\section{Proximate composition of malted sorghum-soy flour}

The results of the proximate composition of the composite flour are shown in Table 2. The moisture content of the composite flour varied significantly $(\mathrm{p}<0.05)$ from each other. The moisture content ranged from $5.66 \%$ to $6.76 \%$, with Sample A (100\% malted sorghum flour) having the highest moisture content $(6.76 \%)$ while sample E ( $40 \%$ soy flour substitution) had the lowest value (5.66\%). The moisture content of the composite flour is closer to the moisture content of wheat flour (7.00\%). However, higher moisture content was reported for wheat bread substituted with $40 \%$ soy flour $(28.5-39.5 \%)$ by Ndife et al. [8]. Rita and Sophia [15] also reported higher moisture content (21.9$36.9 \%$ ) for bread produced from wheat flour substituted with $20 \%$ soy flour. The moisture content of all the malted sorghum-soy composite flour reported in this study is within the recommended moisture contents of dried foods. This shows that the composite flour can be stored at room temperature for long period without been attack by micro-organism or mold.

The protein content of the malted sorghum-soy composite flour increased with increasing soy flour substitution in the mixes. Protein content of the composite flour ranged from $7.29 \%$ to $19.19 \%$ (Table 2 ). The protein content of the five formulations and the $100 \%$ wheat flour $(13.9 \%)$ were significantly different $(p<0.05)$ from each other. Among the composite flour, malted-sorghum flour with $40 \%$ soy flour substitution had the highest protein content $(19.19 \%)$ while the lowest value (7.29\%) was observed in sample A ( $100 \%$ malted sorghum flour). The increased in the protein content of the composite flour could be due to high protein content of soybean $[16,17]$. Similar studies also reported high protein content for soy-maize 'agidi" [18] and wheatsoy plantain bread [19]. High crude protein of the malted sorghumsoy flour signifies that the composite flour can serve as cheap source of protein to African populace. Products from the flour would have the potential of solving the problem of protein-energy malnutrition in Africa.

The ash content of the malted sorghum-soy flour increased with increasing substitution with soy flour. The ash content ranged from $1.65 \%$ to $3.14 \%$ (Table 2). Composite flour with $40 \%$ soy flour substitution had the highest ash content $(3.14 \%)$ while the lowest value $(1.65 \%)$ was observed in $100 \%$ malted sorghum flour. There was significant difference $(\mathrm{p}<0.05)$ in the ash content of the composite flour and $100 \%$ wheat flour $(1.50 \%)$. The increased noted in the ash content of the malted sorghum-soy flour may be attributed to the higher mineral content of soybean. The ash content of a food material could be used as an index of mineral constituents of the food [20]. Legumes have been reported to be good sources of ash. The ash content (1.7-3.1\%) of the composite flour reported in this study is similar to the ash content (2.9\%) of composite flour produced from maize-soy flour [21].

The fat content of the composite flour also increases with increasing substitution with soy flour (Table 2). Fat content of the composite flour ranged from $2.49 \%$ to $9.26 \%$. Among the flour samples, malted sorghum with $40 \%$ soy flour blend had the highest fat content $(9.26 \%)$ while the lowest value $(2.49 \%)$ was observed in $100 \%$ malted sorghum flour. Fat was significantly different $(p<0.05)$ for all the formulations. The fat content of the flour was relatively high because un-deffated soy flour was used for the mixes. Alabi et al. [22] also reported that sorghumsoy composite flour contain (3.6\%) of fat. The fat content (2.49-9.26\%) of the malted sorghum-soy flour obtained in this study is in line with the fat content (4.-6.2\%) of rice and soy flour blends [23] and the fat content (4.5-7.1\%) of wheat and soy composite flour reported by Ndife et al. [24].

The fiber content of the composite flour varied from $3.6 \%$ to $4.4 \%$ (Table 2). Sample D (30\% soy flour substitution) had the highest crude

\begin{tabular}{|c|c|c|c|c|c|c|}
\hline Sample & $\begin{array}{c}\text { Moisture } \\
\text { content } \\
(\mathbf{\%})\end{array}$ & $\begin{array}{c}\text { Protein } \\
\mathbf{( \% )}\end{array}$ & $\begin{array}{c}\text { Ash } \\
\mathbf{( \% )}\end{array}$ & $\begin{array}{c}\text { Fat } \\
\mathbf{( \% )}\end{array}$ & $\begin{array}{c}\text { Crude } \\
\text { Fibre } \\
\mathbf{( \% )}\end{array}$ & $\begin{array}{c}\text { Carbohydrate } \\
(\mathbf{\%})\end{array}$ \\
\hline A & 6.76 & 7.29 & 1.65 & 2.49 & 3.64 & 78.18 \\
\hline B & 6.41 & 9.66 & 2.08 & 4.11 & 3.92 & 73.83 \\
\hline C & 6.08 & 12.68 & 2.57 & 5.92 & 4.27 & 68.56 \\
\hline D & 5.99 & 16.19 & 2.64 & 7.41 & 4.61 & 63.17 \\
\hline E & 5.66 & 19.19 & 3.14 & 9.26 & 4.38 & 58.38 \\
\hline F & 7.00 & 13.90 & 1.50 & 3.60 & 4.50 & 69.50 \\
\hline
\end{tabular}

Values are mean \pm Standard deviation of triplicate determinations. Means with the same superscripts within the same column are not significantly different $(P>0.05)$ Means with different superscripts are significantly different $(P<0.05)$.

Sample $A=100 \%$ malted-sorghum flour; $B=90 \%$ malted-sorghum flour $+10 \%$ soy flour; $C=80 \%$ malted-sorghum flour $+20 \%$ soy flour; $D=70 \%$ malted-sorghum flour $+30 \%$ soy flour; $E=60 \%$ malted-sorghum flour $+40 \%$ soy flour; $F=100 \%$ wheat flour.

Table 2: Proximate composition of malted sorghum-soy flour mixes. 
fiber (4.38\%) while the lowest fiber (3.64\%) was recorded for $100 \%$ malted sorghum flour. The fiber content were significantly different $(\mathrm{p}$ $<0.05$ ) for all the formulations and higher when compared with $100 \%$ wheat flour (2.5\%). This may be due to the higher fibre content in soy flour. The fiber content (3.64-4.38\%) obtained in this study is in line with the fiber content (3.3-5.7\%) of wheat and soy composite flour reported by Ndife et al. [24]. However, lower fibre content (1.2-1.72\%) was reported for rice and soy bean flour blends [23].

Highest carbohydrate content was observed in $100 \%$ maltedsorghum flour $(78.18 \%)$ while $40 \%$ soy flour substitution had the lowest value (58.38\%). Carbohydrate content of the malted sorghumsoy flour varied significantly $(\mathrm{p}<0.05)$ when compared to $100 \%$ wheat flour $(69.50 \%)$ and decreased with increased in the proportion of the soy flour in the mixes. These results showed that soy beans are not good sources of carbohydrate when compared to other legumes [25]. The results obtained in this study is similar to the findings of Okoye et al. [26] who reported a decrease in carbohydrate content (73.4$34.9 \%$ ) of wheat-soy bean flour with increasing soy flour substitution. Oluwamukomi et al. [27] also reported carbohydrate content of 69.2$74.5 \%$ for wheat-cassava and soy composite flour. The low carbohydrate content of the malted sorghum-soy flour indicates that products from the flour will be acceptable to patient with diabetics and other related health problems.

\section{Mineral composition of malted sorghum-soy flour}

The results of the mineral composition of the composite flour are presented in Table 3. The iron, calcium and zinc content of the composite flour increased with increasing soy flour substitution with malted-sorghum flour, while the phosphorous content decreased as the proportion of soy flour increases in the composite flour mixes. The iron and calcium content of the composite flour produced in this study is higher than the iron $(0.013 \mathrm{mg} / 100 \mathrm{~g})$ and calcium content $(0.016$ $\mathrm{mg} / 100 \mathrm{~g}$ ) of wheat-sorghum composite flour reported by Ranya et al. [28]. Similarly, calcium content of $0.062,0.052$ and $0.060 \mathrm{mg} / 100 \mathrm{~g}$ was reported for three Sudanese sorghum (Dabar, Fakimustahi and Tetron) cultivars by Taha [29]. These values were lower than the calcium content $(0.093-0.119 \mathrm{mg} / 100 \mathrm{~g})$ of malted sorghum-soy flour obtained in this study. High calcium and iron content of the composite flour shows that products from the flour would be nutritionally beneficial for both children and elderly people who requires high iron and calcium intake for strong bone, blood formation and body development.

The zinc content $(0.030-0.044 \mathrm{mg} / 100 \mathrm{~g})$ of malted sorghum-soy bean flour produced in this study is lower than the zinc content $(0.053$ and $0.092 \mathrm{mg} / 100 \mathrm{~g}$ ) of wheat flour and wheat-soy flour reported by

\begin{tabular}{|c|c|c|c|c|}
\hline Sample & $\begin{array}{c}\mathbf{F e} \\
\mathbf{( m g / 1 0 0} \mathbf{g})\end{array}$ & $\begin{array}{c}\mathbf{C a} \\
\mathbf{( m g / 1 0 0} \mathbf{g})\end{array}$ & $\begin{array}{c}\mathbf{Z n} \\
\mathbf{( m g / 1 0 0} \mathbf{g})\end{array}$ & $\begin{array}{c}\mathbf{P} \\
\mathbf{( m g / 1 0 0 ~} \mathbf{~})\end{array}$ \\
\hline $\mathrm{A}$ & 0.144 & 0.093 & 0.030 & 180 \\
\hline $\mathrm{B}$ & 0.148 & 0.100 & 0.031 & 177 \\
\hline $\mathrm{C}$ & 0.150 & 0.104 & 0.039 & 175 \\
\hline $\mathrm{D}$ & 0.159 & 0.118 & 0.042 & 168 \\
\hline E & 0.166 & 0.119 & 0.044 & 16 \\
\hline
\end{tabular}

Values are mean \pm Standard deviation of triplicate determinations. Means with the same superscripts within the same column are not significantly different $(P>0.05)$. Means with different superscripts are significantly different $(P<0.05)$.

Sample $A=100 \%$ malted-sorghum flour; $B=90 \%$ malted-sorghum flour $+10 \%$ soy flour; $C=80 \%$ malted-sorghum flour $+20 \%$ soy flour; $D=70 \%$ malted-sorghum flour $+30 \%$ soy flour; $E=60 \%$ malted-sorghum flour $+40 \%$ soy flour; $F=100 \%$ wheat flour.

Table 3: Mineral composition of malted sorghum-soy flour mixes.
Anna et al. [30] and closer to the zinc content $(0.096 \mathrm{mg} / 100 \mathrm{~g})$ of pearl millet flour reported by Pelig-Ba [31]. The presence of zinc in the composite flour is an indication that products from the flour will be good for pregnant women.

Phosphorous was the most abundant mineral (163-180 mg/100 g) in the composite flour (Table 3). The Phosphorous content of the composite flour decreases with increased soy flour substitution. The highest phosphorus content $(180 \mathrm{mg} / 100 \mathrm{~g})$ was recorded for sample A (100\% malted sorghum flour) while the lowest value $(163 \mathrm{mg} / 100 \mathrm{~g})$ was observed in sample E (malted sorghum flour with $40 \%$ soy flour substitution). This result indicated that malting of sorghum greatly increased the availability of minerals (iron, calcium and zinc) while the phosphorous content was reduced probably due to the fact that soy bean is not a good source of phosphorus [32]. The increased in minerals availability is likely due to the reduction in phytate and tannin content of the composite flour [33]. The phosphorus content of the composite flour produced in this study is closer to the phosphorus content (183.1 $\mathrm{mg} / 100 \mathrm{~g}$ ) of wheat-soy flour reported by Anna et al. [30]. The relatively high phosphorus content of the composite flour is an indication that the flour products will help in the formation of teeth and bones in children and their proper development.

\section{Anti-nutritional contents of malted sorghum-soy flour}

The anti-nutritional content of the composite flour blends are shown in Table 4. The $100 \%$ malted sorghum flour had the highest tannin content $(27.6 \%)$ while substitution with $40 \%$ soy flour has the lowest value (18.9\%). Obviously, substitution of malted sorghum flour with $10 \%$ soy flour resulted in significant $(\mathrm{p}<0.05)$ decreased in the level of tannin in the composite flour. The tannin content (18.9-22.9\%) of the malted sorghum-soy composite flour obtained in this study is lower than the tannin content (23.8-26.7\%) of sorghum cultivars [34] and sorghum-soy-plantain flour (23.8-27.4\%) reported by Onoja et al. [35]. Ogbonna et al. [36] reported higher tannin content (35.8\%) for malted sorghum flour. Lower tannin content observed in this study could be due to degradation of tannin during malting. Tannins impart a bitter taste to the grains making them unpalatable and also interfere with protein digestibility [37].

The phytate content of the malted sorghum-soy composite flour decreases with increasing soy flour substitution (Table 4). Maltedsorghum flour with no soy flour substitution had the highest phytate content while the lowest value was observed in composite flour substituted with $40 \%$ soy flour. Doherty et al. [38] analyzed several varieties of sorghum and found that phytin phosphorous ranged from 170 to $380 \mathrm{mg} / 100 \mathrm{~g}$ in whole sorghum grain. Thus, he concluded that over $85 \%$ of the total phosphorous in the whole grain was bound as

\begin{tabular}{|c|c|c|}
\hline Sample & Tannin (\%) & Phytate (\%) \\
\hline A & 27.6 & 39.4 \\
\hline B & 22.9 & 36.8 \\
\hline C & 20.9 & 29.8 \\
\hline D & 20.0 & 28.6 \\
\hline E & 18.9 & 25.7 \\
\hline
\end{tabular}

Values are mean \pm Standard deviation of triplicate determinations. Means with the same superscripts within the same column are not significantly different $(P>0.05)$. Means with different superscripts are significantly different $(P<0.05)$.

Sample $A=100 \%$ malted-sorghum flour; $B=90 \%$ malted-sorghum flour $+10 \%$ soy flour; $C=80 \%$ malted-sorghum flour $+20 \%$ soy flour; $D=70 \%$ malted-sorghum flour $+30 \%$ soy flour; $E=60 \%$ malted-sorghum flour $+40 \%$ soy flour; $F=100 \%$ wheat flour.

Table 4: Anti-nutritional composition of malted sorghum-soy flour. 
phytin-phosphrous. The phytate content of malted sorghum-soy flour (25.7-39.4\%) reported in this study is similar to the phytate content (39.4\%) of raw oat cereal [39]. Idris et al. [34] also reported phytate content of $36.6 \%$ for malted sorghum flour.

\section{Functional properties of malted sorghum-soy flour}

The essence of determining the functional properties of the composite flour was for identification of the usage of the flour for food application or product development. Table 5 showed the results of the functional properties of the malted sorghum-soy flour mixes. The bulk density of food materials is affected by the particle size and the density of the food. Bulk density is an important factor in food packaging. The bulk density of the composite flour decreased with increasing level of soy flour substitution in the mixes, with $100 \%$ malted sorghum flour being denser than the substituted samples (Table 5). This indicates a lesser package requirement with increasing in soy flour substitution. The bulk density of plantain-soy flour mixes was reported to be 0.46 $0.42 \mathrm{~g} / \mathrm{cm}^{3}$ [32]. These values are close to the bulk density of malted sorghum-soy flour reported in this study.

The $\mathrm{pH}$ value of malted sorghum flour substituted with $40 \%$ soy flour was higher than that of the other samples. This shows that acidity decreases with increasing soy flour substitution and that the composite flour is not acidic. The flour can therefore be used to produce acceptable products for people suffering from stomach or pectic ulcer. The $\mathrm{pH}$ values (5.73 to 6.33) of the composite flour are similar to the $\mathrm{pH}$ values (5.60 to 6.7) reported by Adenekan and Oyewole [40] for "Ogi" produced from germinatedsorghum supplemented with soybeans.

The water absorption capacity (WAC) is important in the development of ready to eat foods, and a high WAC may assure product cohesiveness [41], a low WAC product will be easily digestible. WAC of the malted sorghum-soybean mixes decreased with soy flour substitution. The WAC of the composite flour (1.71 to $1.87 \%$ ) obtained in this study is lower than the values (18 to $72 \%$ ) reported for sorghum-fermented cassava flour blend [42]. Low WAC of the composite flour could be due to high protein content of soy flour. However, the addition of soy flour to malted-sorghum flour improves textural ability of the mixes.

The swelling capacity also decreased with soy flour substitution. Swelling capacity is an indication of the presence of amylase which influences the quantity of amylose and amylopectin present in the malted sorghum flour. The higher the swelling capacity, the higher the associate forces [43].

\section{Pasting characteristic of malted sorghum-soy flour}

\begin{tabular}{|c|c|c|c|c|}
\hline Sample & BD $\left(\mathbf{g} / \mathbf{c m}^{\mathbf{3}}\right)$ & PH & WAC (\%) & SC $\mathbf{( g / g )}$ \\
\hline A & 0.67 & 5.50 & 1.97 & 1.27 \\
\hline B & 0.64 & 5.73 & 1.87 & 1.26 \\
\hline C & 0.63 & 6.05 & 1.77 & 1.24 \\
\hline D & 0.62 & 6.10 & 1.75 & 1.23 \\
\hline E & 0.60 & 6.33 & 1.71 & 1.21 \\
\hline
\end{tabular}

Values are mean \pm Standard deviation of triplicate determinations. Means with the same superscripts within the same column are not significantly different $(P>0.05)$. Means with different superscripts are significantly different $(P<0.05)$.

Sample $A=100 \%$ malted-sorghum flour; $B=90 \%$ malted-sorghum flour $+10 \%$ soy flour;

$\mathrm{C}=80 \%$ malted-sorghum flour $+20 \%$ soy flour; $\mathrm{D}=70 \%$ alted-sorghum flour $+30 \%$ soy flour;

$E=60 \%$ malted-sorghum flour $+40 \%$ soy flour; $F=100 \%$ wheat flour.

BD =Bulk Density, WAC = Water Absorption Capacity, SC = Swelling Capacity

Table 5: Functional properties of malted sorghum-soy flour mixes.
Peak viscosity is a measure of the ability of starch to form a paste on cooking. The result of the pasting properties indicated that the peak viscosity values decreased owing to the addition of soy flour (Table 6). The relatively low peak viscosity is an indication that the composite flour will be suitable for product requiring low gel strength and elasticity [32].

Trough is the minimum viscosity which measures the ability of paste to withstand breakdown during cooling. The trough ranged between 35.00 to $40.50 \mathrm{RVU}$ (Table 6). The final viscosity is an important parameter in predicting and defining the final textural quality of food in terms of its hardness and elasticity. The setback decreased with increased in soy flour substitution level. The higher the substitution level, the more the retro gradation level during cooling and the higher the staling of the products made from the flour [32,44]. A high set back value is associated with a cohesive paste while a low value is an indication that the paste is not cohesive [45]. The peak time is an indication of the cooking time. The pasting temperature provides an indication of the minimum temperature required to cook a given sample. Results from Table 6 showed that the pasting time and temperature decreased with increasing soy flour substitution in the mixes. This indicates that less time and low temperature will be required to cook the composite flour products. The result of the pasting properties of malted sorghum-soy flour reported in this study was lower than the pasting properties of cassava-sorghum and soy-plantain composite flour [32,41]. This observed lower pasting properties value may be due to the difference in materials used.

\section{Sensory properties of malted sorghum-soy flour}

The sensory scores of the thick paste produced from malted sorghum-soy composite flour revealed various significant differences in all the parameters evaluated (Table 7). All the samples were equally rated by the panelist in terms of color. Samples with 0 and $10 \%$ soy flour substitution had no significant difference at $5 \%$ probability level in all the quality parameters evaluated. However, samples substituted with 20,30 and $40 \%$ soy flour were significantly different from the 0 and $10 \%$ soy flour substitution in terms of aroma, texture and taste. In terms of general acceptability, samples with 0 and $10 \%$ soy flour were mostly acceptable to the panelist. Thus, composite flour produced from malted sorghum flour with $10 \%$ soy flour substitution could be used to produce organoleptically acceptable product.

\section{Conclusion}

The malted sorghum-soy composite flour produced in this study was found to be nutritionally superior (in terms of protein, fat and crude fiber) to wheat flour. Substitution of malted-sorghum flour with $40 \%$ soy flour resulted in notable increased in protein content. Thus, the composite flour products would be nutritionally advantageous to Africa, where many people can hardly afford animal protein. Substitution of malted-sorghum flour with soy flour also resulted in increased in mineral content (iron, calcium, zinc and phosphorus) of the composite flour. The $10 \%$ soy flour substitution was generally accepted by the panelist though the $40 \%$ substituted soy flour had better nutritional quality. Increasing the lowest soy flour substitution level from $10 \%$ to $15 \%$ could result in products with increased nutrient profile and acceptability. The results obtained in this study indicated that highly nutritious flour can be produced from malted sorghum-soy composite flour. Industrial production of this flour will greatly increase the utilization of sorghum in developing countries where the crop has not been optimally utilized. The composite flour could also serve as cheaper alternative flour to wheat flour. In addition, consumption of 
Citation: Bolarinwa IF, Olaniyan SA, Adebayo LO, Ademola AA (2015) Malted Sorghum-Soy Composite Flour: Preparation, Chemical and PhysicoChemical Properties. J Food Process Technol 6: 467. doi:10.4172/2157-7110.1000467

Page 6 of 7

\begin{tabular}{|c|c|c|c|c|c|c|c|}
\hline Sample & Peak viscosity & Trough & Breakdown & Final viscosity & $\begin{array}{c}\text { Set back } \\
\text { RVU }\end{array}$ & Peak time (mins) & Pasting temp $\left({ }^{\circ} \mathrm{C}\right)$ \\
\hline$A$ & 126.00 & 62.50 & 63.50 & 170.50 & 44.50 & 4.40 & 85.00 \\
\hline B & 86.00 & 40.50 & 45.50 & 114.00 & 28.00 & 4.26 & 74.50 \\
\hline C & 65.00 & 35.50 & 29.50 & 88.00 & 23.00 & 4.20 & 72.50 \\
\hline $\mathrm{D}$ & 63.00 & 34.50 & 28.50 & 84.50 & 21.50 & 4.05 & 71.50 \\
\hline$E$ & 55.50 & 35.00 & 20.50 & 77.50 & 22.50 & 4.00 & 70.00 \\
\hline
\end{tabular}

Sample $A=100 \%$ malted-sorghum flour; $B=90 \%$ malted-sorghum flour $+10 \%$ soy flour; $C=80 \%$ malted-sorghum flour $+20 \%$ soy flour; $D=70 \%$ malted-sorghum flour $+30 \%$ soy flour; $E=60 \%$ malted-sorghum flour $+40 \%$ soy flour; $F=100 \%$ wheat flour.

Peak viscosity = maximum viscosity developed during or after the heating portion of the test; Trough = minimum viscosity after the peak normally occurring after the commencement of the sample cooling; Breakdown = peak viscosity minus trough viscosity; Final viscosity = viscosity at the end of the test; Set back = final viscosity minus peak viscosity. Peak time $=$ time at which the peak viscosity occurred

Table 6: Pasting characteristic of malted sorghum-soy flour mixes.

\begin{tabular}{|c|c|c|c|c|c|}
\hline Sample & Colour & Aroma & Texture & Taste & $\begin{array}{c}\text { General } \\
\text { acceptability }\end{array}$ \\
\hline A & 6.05 & 7.41 & 7.74 & 6.94 & 6.70 \\
\hline B & 7.00 & 7.25 & 7.50 & 6.70 & 6.55 \\
\hline C & 7.25 & 6.30 & 6.20 & 6.12 & 6.20 \\
\hline D & 6.65 & 6.25 & 6.01 & 6.04 & 5.56 \\
\hline E & 6.15 & 6.00 & 5.80 & 6.00 & 5.20 \\
\hline
\end{tabular}

Sample $A=100 \%$ malted-sorghum flour; $B=90 \%$ malted-sorghum flour $+10 \%$ soy flour; $C=80 \%$ malted-sorghum flour $+20 \%$ soy flour; $D=70 \%$ malted-sorghum flour $+30 \%$ soy flour; $E=60 \%$ malted-sorghum flour $+40 \%$ soy flour; $F=100 \%$ wheat flour.

Table 7: Mean score of sensory evaluation of reconstituted paste.

products produced from the flour would help to solve the problem of protein-calorie malnutrition in Africa.

\section{References}

1. Eneche EH (1999) Biscuit making potentials of millets-pigeon pea flour blends. Plant foods Humn Nutri 54: 21-27.

2. FAO (1995) Sorghum and millet in human nutrition. FAO food and nutrition series, Rome, Food and Agriculture Organization of the United Nations.

3. Vimala V, Kaur KJ, Hymavati TV (1990) Processing of millets-scope for diversification. Proceedings of the Summer Institute on Appropriate Food Processing Technologies for a Rural Development. India.

4. Liu K (2000) Expanding soy bean food utilization. J Food Technol 54: 46-59.

5. Fukushima D (1999) Recent progress of soy bean protein foods: Chemistry, technology and nutrition. Food Review Int 7: 323-351.

6. Oyenuga VA (1968) Nigeria's food and feeding stuffs: Their chemistry and nutritive value. Ibadan University press, Nigeria.

7. Hallen E, Ibanglu S, Ainswoth P (2004) Effect of fermented /germinated cowpea flour added on the rheological and bakery properties of wheat flour. J Food Engr 63: 177-184.

8. Ndife J, Abdulraheem LO, Zakari UM (2011) Evaluation of the nutritional and sensory quality of functional breads produced from whole wheat and soybean flour blends. Afri J Food Sci 5: 466-472.

9. AOAC (1990) Official method of analysis of the association of official. Analytical Chemist, (15thedn) Virginia.

10. Okaka JC, Okorie PA, Ozo ON (1991) Quality evaluation of sun dried yam chips. Tropical Sci 31: 265-275.

11. Adebowale AA, Sanni SA, Oladapo FO (2008) Chemical, functional and sensory properties of instant yam breadfruit flour. Nigerian Food J 26: 2-12.

12. Lawal OS, Adebowale KO (2005) Physico-chemical characteristics and thermal properties of chemically modified Jack bean (Canavalia ensiforms) starch. Carb Polym 60: 331-341.

13. Swain T, Hillis WE (1959) The phenolic constituents of Prunes domestica I. The quantitative analysis of phenolic constituents. $\mathrm{J}$ of the Sci of Food and Agric 10: 63-68.

14. Ihekoronye IA, Ngoddy PO (1985) Integrated food science and technology for the tropics. Macmillian Publishers Ltd, London.

15. Rita ES, Sophia D (2010) Utilisation of soy bean flour in the production of bread. Pakist J Nutrition 9: 815-818.

16. Kure OA, Bahago EJ, Daniel EA (1998) Studies on the proximate composition and effect of flour particle size of acceptability of biscuits produced from blends and plantain flours. Namoda Tech Scope J 3: 17-22.

17. Basman AH, Koksel PKW (2008) Utilization of Transgluranae use to increase the level of barley and soy flour incorporate in wheat flour breads. J Food Sci 68: 2453-2460.

18. Akpapunam MA, Badifu GIO, Etokudo EP (1997) Production and quality characteristics of Nigerian "Agidi" supplemented with soy flour. J Food Sci Technol 34: 143-145.

19. Olaoye OA, Onilade AA, Idowu OA (2006) Quality characteristics of bread produced from Composite flour of wheat, plantain and soybeans. Afr J Biotechnol 5: 1102-1106.

20. Sanni SA, Adebowale AA, Olayiwola IO, Maziya D (2008) Chemical composition and pasting properties of iron fortified maize flour. J Food Agric Environ 6:172175 .

21. Edema MO, Sanni LO, Sanni Al (2005) Evaluation of maize-soybean flour blends for sour maize bread production in Nigeria. Afri J Biotechnol 4: 911-918.

22. Alabi MO, Anuonye JC (2007) Nutritional and sensory attributes of soysupplemented cereal meals. Nigerian Food J 25: 100-110.

23. Falola AO, Olatidoye OP, Balogun IO, Opeifa AO (2013) Evaluation of nutritional, physicochemical properties and acceptability of un-dehulled 'ofada' rice and soy bean flour blends. J Agric Veter Sci 5: 118-128.

24. Ndife J, Kida F, Fagbemi S (2014) Production and quality assessment of enriched cookies from whole wheat and full fat soya. Europe J Food Sci Technol 2: 19-28.

25. Salunkhen DK, Chavan JC, Adsule RN (1992) World oil seed, chemistry,technology and utilization. Springer, New York, USA.

26. Okoye JI, Nkwocha AC, Ogbonnaya AE (2008) Production, proximate composition and consumer acceptability of biscuits from wheat-soybean flour blends. Conti. $J$ Food Sci Technol 2: 6-13.

27. Oluwamukomi MO, Oluwalana IB, Akinbowale OF (2011) Physico chemical and Sensory properties of wheat-cassava composite biscuit enriched with soy flour. Afri J Food Sci 5: 50-56.

28. Ranya FA, Abdel Moneim IM, Amir MH, Yuanhong RC, Padmanaban GK (2013) Effects of sorghum flour addition on chemical and rheological properties of hard white winter wheat. Adv J Food Sci Technol 5: 1407-1412.

29. Taha AOM (2000) The Role of sorghum flour starches (amylose/amylopectin) in composite bread quality. Thesis Report, University of Khartoum, Sudan.

30. Anna WM, Malgorzata K (2011) Evaluation of the mineral composition of breadstuff and frequency of its consumption. Acta Scientia Polonor Technol Alimentr 10: 487-495.

31. Pelig-Ba KB (2009) Assessment of phytic acid levels in some local cereal grains in two districts in the upper east region of Ghana. Pakist J Nutri 8: 1540-1547.

32. Abioye VF, Ade-Omowaye BIO, Babarinde GO, Adesigbin MK (2011) Chemical physico-chemical and sensory properties of soy-plantain flour. Afric J Food Sc 5: 176-180. 
Citation: Bolarinwa IF, Olaniyan SA, Adebayo LO, Ademola AA (2015) Malted Sorghum-Soy Composite Flour: Preparation, Chemical and PhysicoChemical Properties. J Food Process Technol 6: 467. doi:10.4172/2157-7110.1000467

Page 7 of 7

33. Rakhi G, Khetarpau N (1995) Effect of fermentation on $\mathrm{HCl}$ extractability of minerals from rice-defatted soy flour blend. Food Chem 50: 419-422.

34. Idris HW, Hassan AD, Babiker EE, EITinay AH (2005) Effect of malt pretreatment on anti-nutritional factors and $\mathrm{HCl}$ extractability of minerals of sorghum cultivars. Pakistan J Nutri 4: 396-401.

35. Onoja US, Akubor PI, Gernar DI, Chinmma CE (2014) Evaluation of complementary food formulated for staples and fortified with calcium, iron and zinc. J Nutr Food Sci 4: 1-6.

36. Ogbonna AC, Abuajah $\mathrm{Cl}$, Ide EO, Udofia US (2012) Effect of malting conditions on the nutritional and anti-nutritional factors of sorghum grist. Food Technol 6 : 64-72.

37. Harris HB, Burns RE (1970) Influence of tannin content on pre harvest germination in sorghum. Agron J 62: 835-836.

38. Doherty C, Faubion JM, Rooney LW (1982) Semi-automated determination of phytate in sorghum and sorghum products. Cereal Chem 59: 373-378.

39. Norhaizan ME, Norfaizadatul AA (2009) Determination of phytate, iron, zinc, calcium contents and their molar ratios in commonly consumed raw and prepared food in Malaysia. Mal J Nutr 15: 213-222.

40. Adenekan AO, Oyewole OB (2010) Production of 'Ogi' from germinated sorghum supplemented with soybeans. Afric J Biotechnol 9: 7114-7121.

41. Housson P, Ayenor GS (2002) Appropriate processing and food functional properties of maize flour. Afr J Sci Technol 3:126-121.

42. Osungbaro TO, Taiwo O, Jimoh D, Osundeyi E (2010) Functional and pasting properties of composite Cassava-Sorgum flour meals. Agric Biol J North Amer 1: 715 .

43. Ruales J, Valencia S, Nair B (1993) Effect of processing on the physiochemical characteristics of guinea flour. (Chenopodium guinea Wild) starch - Stärke 45: 13-19.

44. Adeyemi IA, Idowu MA (1990) The evaluation of pre-gelatinized maize flour in the development of Maissa, a baked product. Nigerian Food J 8: 63-73.

45. Oduro I, Ellis WO, Aryeetey SK, Ahenkora K, Otoo JA (2000) Pasting characteristics of starch from new varieties of sweet potato. Trop Sci 40: 25-28. 